\title{
Energy Consumption and Economic Growth: A Trivariate Framework of South Africa
}

\author{
Walter Trevor Shiba* ${ }^{*} \quad$ Yongchang Wu Wenshan Wei \\ Institute of Agricultural Economics and Development, Graduate School of Chinese Academy of Agricultural \\ Sciences, 12 South Avenue, Zhong Guan Cun, Beijing 100081, China
}

\begin{abstract}
The study investigates the causal relationship between energy consumption and economic growth in South Africa, covering the period of 1980-2014. In a trivariate framework which includes electricity and inflation as additional variables by applying the Autoregressive Distributed Lag (ARDL) integration method. First unit root test was employed; results indicated that all variables were non-stationary at the level and stationary at their first differences, using the Augmented Dickey-Fuller (ADF) and Phillips-Perron (PP). The results show a long-run relationship among the variables using the ARDL integration approach. The Granger causality test indicates a unidirectional running from inflation to economic growth, which supports the growth hypothesis as documented in the literature and there was no causality between electricity consumption and economic growth, supporting the neutrality hypothesis. Any policies concerning energy consumption should be re-evaluated to confirm that it will not disturb economic growth.
\end{abstract}

Keywords: ARDL, Economic Growth, Energy Consumption, Granger Causality, and South Africa.

DOI: $10.7176 / \mathrm{JESD} / 10-8-12$

Publication date: April $30^{\text {th }} 2019$

\section{Introduction}

Energy plays a crucial role in the economic development of a country and is a key to achieve a solid economic, social and environmental aims of sustainable development. Policy makers and researches and economists of South Africa need to apprehend which variables among the five in question cause another. So that, the right strategies can be identified and implemented that will have a major impact on economic development. Therefore, investigating the impact of energy consumption on economic growth is crucial in explaining which variable plays a major role in the economic growth of South Africa. The association between energy consumption and economic growth is now well established in the literature, yet the direction of causality of this relationship remains controversial see Asafu-Adjaye (2000); Glasure and Lee (1997); and Masih and Masih (1997). The big question is, whether energy consumption leads to economic growth or vice versa, is still debatable.

In this case, it seems equitable to undertake studies on the relation between economic growth, energy consumption, capital, and inflation. From a theoretical point of view, these variables have a tendency to impact one another. Therefore, without a deep understanding of the direction of these variables, it will be difficult to find the most effective policies to be implemented. Then, it makes sense to investigate the causality relation between these variables to make it easier in policy making in South Africa. The direction of causality has an impact on policy implication. Few studies have focused on economic growth, electricity consumption, energy use, capital, and inflation. The nexus between energy consumption and economic growth has been widely studied over the years, using modern advances in time series econometrics of co-integration and causality. Although to the best of our knowledge few studies have been conducted about South Africa.

The purpose of this study is to provide a recent understanding of analysis in the five variables in question and add up to the existing literature, while the specific objective is to investigate the causal relationship between gross domestic product and energy consumption in the case of South Africa. This is accomplished by examining the unit root tests to test for stationarity of the variables, then, co-integration test by employing autoregressive distributed lag (ARDL) bounds testing approach proposed by Pesaran et al. (2001). Pairwise Granger causality test to determine the direction of the variables and diagnostic tests are conducted to check whether the variables are free from heteroscedasticity, correlation, and normality problems, while stability test is used to check if coefficients are stable or not.

This study is organized into five parts, Parts One covers the introduction of the study, Part Two Review of literature, Part Three covers the data and methodology, Part Four is the empirical results and discussion, and Part Five covers conclusion and recommendation.

\section{Review of Literature}

Since the seminar study of Kraft and Kraft (1978), the literature on economic growth and energy consumption has been growing. The view that energy consumption is of the basic indicators of economic growth has concerned economists all over the world to investigate the correlation between economic growth and energy consumption. Ozturk (2010) summarized the empirical evidence of testing the causality relation between economic growth and 
energy consumption into four testable hypotheses namely; the feedback, conservation, growth, and neutrality. First, the feedback hypothesis refers to a state in which causality runs from both directions that are from energy consumption to economic growth and vice versa. It entails that energy consumption and economic growth are interrelated. Studies that support feedback or bidirectional causality include Masih and Masih (1997) for Pakistan; Jumbe (2004) for Malawi; Belloumi (2009) for Tunisia; Zhang (2011) for Russia; Amusa and Leshoro (2013) for Botswana. Second, the conservation hypothesis refers to a state in which a unidirectional causality runs from economic growth to energy consumption. It implies that guidelines intended to reduce energy consumption will not adversely affect economic growth indicating that the economy is less energy dependent. The conservation hypothesis was demonstrated by Odhiambo (2014); Baranzini et al. (2013) for Switzerland; Azlina (2012) for Malaysia; Akinlo (2008a) for Nigeria; and Zhang and Cheng (2009) for China. Third, a condition in which unidirectional causality runs from energy consumption to economic growth is referred as growth hypothesis. It suggests that a growth in energy consumption may contribute to economic growth, while a decrease in energy consumption may adversely affect economic growth, indicating that the economy is energy dependent. This hypothesis is illustrated by Aslan et al. (2014) for the United States; Tsai (2010) for Greece; Narayan and Smyth (2005) for Australia; Ouedraogo (2013) for 15 ECOWAS countries; and Soytas and Sari (2003) for G7 countries. Lastly, the neutrality hypothesis asserts a condition in which no causality exists in either direction between economic growth and energy consumption. Numerous studies such as Stern and Enflo (2013); Ozturk and Acaravci (2010) for Albania; Narayan and Prasad (2008) for 30 OECD countries; Wolde-Rufael (2006) for 17 African countries; and Soytas and Sari (2003) supports the neutrality hypothesis. If an increase in economic growth does not cause an increase in energy consumption and vice versa, the neutrality hypothesis is recognized.

Table 1 Selected studies on energy consumption and economic growth

\begin{tabular}{|c|c|c|c|}
\hline Author(s) & Country(s)/Periods & Methodology & Findings \\
\hline Aslan et al. (2014) & Turkey (1968-2008) & $\begin{array}{l}\text { ARDL bound test and Granger } \\
\text { causality test }\end{array}$ & $\begin{array}{l}\text { Bi-directional } \\
\text { causality }\end{array}$ \\
\hline Odhiambo (2014) & Ghana (1972-2006) & $\begin{array}{l}\text { ARDL-Bounds } \\
\text { Procedure }\end{array}$ & $\begin{array}{l}\text { Unidirectional } \\
\text { causality test }\end{array}$ \\
\hline Amusa and Leshoro (2013) & Botswana (1981-2010) & $\begin{array}{l}\text { ARDL-Bounds } \\
\text { Procedure }\end{array}$ & $\begin{array}{l}\text { Bi-directional } \\
\text { causality }\end{array}$ \\
\hline Baranzini et al. (2013) & Switzerland & & $\begin{array}{l}\text { Unidirectional } \\
\text { causality }\end{array}$ \\
\hline Ouedraogo (2013) & $\begin{array}{l}15 \text { ECOWAS Countries } \\
(1980-2008)\end{array}$ & $\begin{array}{l}\text { Panel Co-integration, } \\
\text { Causality Tests }\end{array}$ & $\begin{array}{l}\text { Unidirectional } \\
\text { causality }\end{array}$ \\
\hline Stern and Enflo (2013) & Sweden $(1850-2000)$ & Granger Causality & No causality \\
\hline Azlina (2012) & Malaysia & Multivariate & $\begin{array}{l}\text { Unidirectional } \\
\text { causality }\end{array}$ \\
\hline Zhang (2011) & Russia (1970-2008) & Toda-Yamamoto & $\begin{array}{l}\text { Bi-directional } \\
\text { causality }\end{array}$ \\
\hline Akinlo (2008a) & Nigeria (1980-2006) & VECM. Co-Feature Analysis & $\begin{array}{l}\text { Unidirectional } \\
\text { causality }\end{array}$ \\
\hline Tsai (2010) & Greece (1960-2006) & $\begin{array}{l}\text { Toda-Yamamoto } \\
\text { Test }\end{array}$ & $\begin{array}{l}\text { Unidirectional } \\
\text { causality }\end{array}$ \\
\hline $\begin{array}{l}\text { Ozturk and Acaravci } \\
(2010)\end{array}$ & Turkey (1968-2005) & $\begin{array}{l}\text { ARDL-Bounds } \\
\text { Procedure }\end{array}$ & No causality \\
\hline Belloumi (2009) & Tunisia (1971-2004) & VECM & $\begin{array}{l}\text { Bidirectional } \\
\text { causality }\end{array}$ \\
\hline Zhang and Cheng (2009) & China (1960-2007) & $\begin{array}{l}\text { Toda-Yamamoto Test, } \\
\text { Generalized Impulse Response }\end{array}$ & $\begin{array}{l}\text { Unidirectional } \\
\text { causality }\end{array}$ \\
\hline Narayan and Prasad (2008) & 30 OECD Countries & Bootstrapped Causality tests & No causality \\
\hline Wolde-Rufael (2006) & $\begin{array}{l}17 \text { African Countries (1971- } \\
\text { 2001) }\end{array}$ & $\begin{array}{ll}\text { ARDL-Bounds } & \text { Testing } \\
\text { Procedure } & \end{array}$ & No causality \\
\hline Narayan and Smyth (2005) & Australia (1966-1999) & Structural Break Test & $\begin{array}{l}\text { Unidirectional } \\
\text { causality }\end{array}$ \\
\hline Jumbe (2004) & Malawi (1970-1999) & Granger Causality & $\begin{array}{l}\text { Bi-directional } \\
\text { causality }\end{array}$ \\
\hline Soytas and Sari (2003) & & & No causality \\
\hline Masih and Masih (1997) & India & MVECM & $\begin{array}{l}\text { Bi-directional } \\
\text { causality }\end{array}$ \\
\hline Kraft and Kraft (1978) & United States (1947-1974) & Sims causality test & $\begin{array}{l}\text { Unidirectional } \\
\text { causality }\end{array}$ \\
\hline
\end{tabular}


The review of literature indicates that the direction of causality between energy consumption and economic growth remains debated and provide mixed results, therefore making this study a meaningful exercise, especially with the use of recent data and methodology.

\section{Data and Methodology}

\subsection{Data Source}

Annual time series data covering the period of 1980-2014 was used and drawn from the World Development Indicators (World Bank 2018). The limitation of this time period was due to the unavailability of the data. The real GDP per capita (constant 2010 US\$) is the proxy of economic growth and the dependent variable, electricity consumption (kWh per capita), and the annual rate of inflation (percentage) as explanatory variables. All variable are in their natural logarithm. Eviews 10 was employed to estimate the model.

In order to avoid spurious relation among the variables, two different unit root test, namely Augmented Dickey-Fuller (ADF) and Phillips-Perron (PP) were conducted in the time series variables for the gross domestic product, capital, energy use, and inflation. After the unit root testing, it is important to test for the existence of cointegration among variables, this study employed the ARDL model. Lastly, the Granger causality test was employed to determine the direction of the causal relation of the variables. To be sure that the model is robust, diagnostic tests have been conducted to check whether the variables are free from heteroscedasticity, correlation, and normality problems, while stability test is used to check if coefficients are stable or not.

\subsection{Estimation of ARDL Model}

The approach adopted in this study is ARDL procedure bounds-testing proposed by Pesaran, Shin, and Smith (2001). Following recent studies (see Odhiambo 2014), the generalized ARDL (p, q) model was specified as:

$$
\boldsymbol{Y}_{t}=\gamma_{0 i}+\sum_{i=1}^{p} \delta_{i} \boldsymbol{Y}_{t-1}+\sum_{i=0}^{q} \beta^{\prime}{ }_{i} X_{t-1}+\varepsilon_{i t}
$$

Where $\boldsymbol{Y}^{\prime}{ }_{t}$ is the vector and the variables in $\boldsymbol{X}^{\prime}{ }_{i}$ are allowed to be purely $I(0)$ or $I(0)$ or integrated; $\boldsymbol{\beta}$ and $\boldsymbol{\delta}$ are coefficients; $\gamma$ is the constant; $\mathrm{i}=1, \ldots \mathrm{k} ; \mathrm{p}$, q are optimal lag orders; $\boldsymbol{\varepsilon}_{\boldsymbol{i}}$ is the vector of the error terms unobservable zero mean white noise vector process (serially uncorrelated or independent).

Hypotheses:

$H_{0}: b_{1 i}=b_{2 i}=b_{3 i}=0($ where $\mathrm{i}=1,2,3)$

$H_{1}: b_{1 i} \neq b_{2 i} \neq b_{3 i} \neq 0$

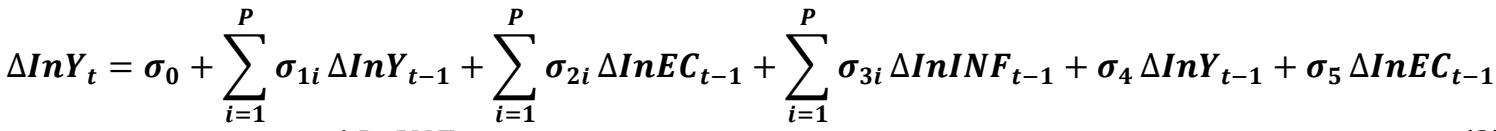

$$
\begin{aligned}
& +\sigma_{6} \Delta I n I N F_{t-1}+\mu_{1 t}
\end{aligned}
$$
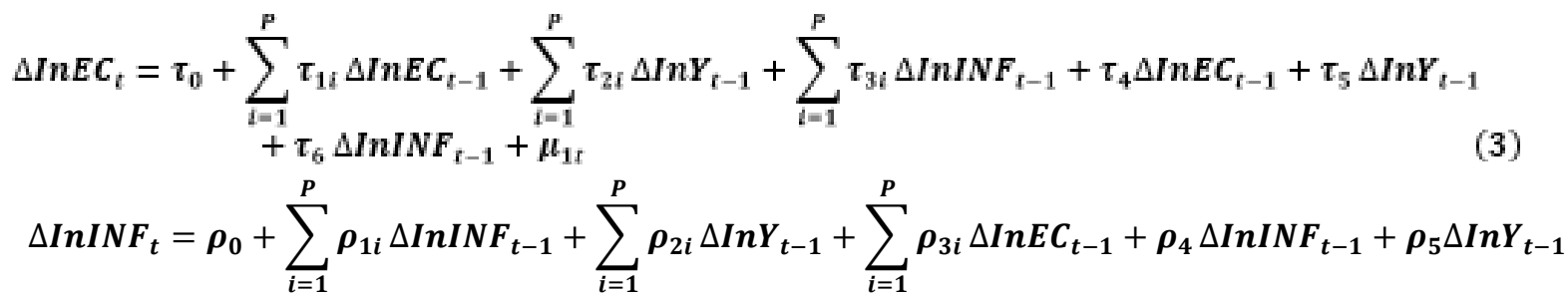

$$
+\rho_{6} \Delta \operatorname{InE} C_{t-1}+\mu_{1 t}
$$

Following the stationarity test, the co-integration analysis is run to make sure that the variables are not cointegrated, that is whether there is any long-run relation among them. This analysis is based on the assumption that the long-run structure of non-stationary series can be stationary Gujarati and Porter, (2009).

To test for co-integration the Autoregressive Distributed Lag (ARDL) approach developed by Pesaran et al. (2001) is applied. This approach has received greater emphasis since a couple of years back due to its ability to return both short-run and long-run multipliers, and its ability to estimate both $I(0)$ and $I(1)$ series in the same model. Furthermore, it is simple to implement and interpret since it only involves just a single equation set-up.

The ARDL co-integration test developed consist of two significant stages, in which during the first stage, the presence of a long-run relationship among the series is examined. Once it is detected, the second stage examines the structure of the short and long-run relation. In summary, to carry out this procedure, the computed F-statistics are compared to the critical lower and upper bound values. The decision rule is that if the F-statistic exceed the critical upper bound value, then the null hypothesis of no co-integration is rejected; if the F-statistic is below the critical lower bound value, then the null hypothesis of no co-integration is accepted; but if the F-statistic fall between the critical lower and upper values, then knowledge of order of integration is required or else it is inconclusive Pesaran et al., (2001). 


\subsection{Granger causality test}

In order to scrutinize the short and long run causality between economic growth, electricity consumption, and inflation the study with previous works (see Odhiambo 2014, Narayan \& Smyth 2005) the model is as follows:

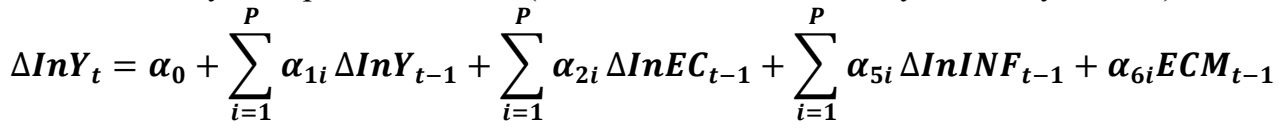

$$
\begin{aligned}
& \Delta I n E C_{t}=\beta_{0}+\sum_{i=1}^{+\mu_{1 t}^{P}} \beta_{1 i} \Delta \operatorname{InE} C_{t-1}+\sum_{i=1}^{P} \beta_{2 i} \Delta \operatorname{In} Y_{t-1}+\sum_{i=1}^{P} \beta_{5 i} \Delta I n I N F_{t-1}+\beta_{6 i} E C M_{t-1} \\
& +\mu_{1 t} \\
& \Delta I n I N F_{t}=\vartheta_{0}+\sum_{i=1}^{P} \vartheta_{1 i} \Delta I n I N F_{t-1}+\sum_{i=1}^{P} \vartheta_{2 i} \Delta I n Y_{t-1}+\sum_{i=1}^{P} \vartheta_{3 i} \Delta I n E C_{t-1}+\vartheta_{6 i} E C M_{t-1}
\end{aligned}
$$

$\boldsymbol{E C} \boldsymbol{M}_{t-1}$ is the error-correction term of the immediate period before $\mathrm{t}$; this term was formulated from the long run equilibrium equation; $\boldsymbol{\alpha}, \boldsymbol{\beta}$ and $\boldsymbol{\gamma}$ are the parameters of the model; and $\boldsymbol{\mu}_{\mathbf{1} t}$ is the error term. The Error correction model specification is the combination of the short-run and long-run representation.

\section{Results and Discussions \\ 4.1 Unit Root Test}

The results of our estimations are presented step by step and are as follows:

Unit root tests were designed to study the stationary properties of time series observation. ADF and PP were used to examine the unit root property with the inclusion of trends and intercepts at both level and first difference. The two tests reveal that all variables are non-stationary in their level data. The results in Table 2 illustrate that all variables are stationary after the first difference, suggesting that all the variables are integrated of order $I(1)$ at $1 \%$ and $5 \%$ level of significance.

Table 2 Unit Root Tests

\begin{tabular}{lllll}
\hline Variables & \multicolumn{1}{c}{ Level } & \multicolumn{3}{c}{ First difference } \\
\hline ADF & PP & ADF & PP \\
InY & -0.4032 & -0.05869 & $-3.5773 * *$ & $-3.6221 * *$ \\
InEC & -2.8761 & -2.8723 & $-4.9231 * * *$ & $-4.8888 * * *$ \\
InINF & -2.1451 & -1.9044 & $-5.4940 * * *$ & $-11.2455^{* * *}$
\end{tabular}

$* * *$ and $* *$ denote $1 \%$ and $5 \%$ level of significance

Source: Author used EViews 10

\subsection{Estimating ARDL Model in Eviews (10)}

Using Model 3 (Constant): Unrestricted constant and no trend

The Autoregressive Distributed Lag (ARDL) model was employed to determine the long-run relation between the variables. Since the variables were found to be stationary $I(1)$, it was likely that they would move together in the long-run. To determine optimal lags, Akaike Information Criterion (AIC) and Schwarz Information Criterion (SIC) were used in the lag structure criteria, the optimal lags deemed appropriate were found to be $(1,2,2$,$) for equation$ 1 to 3. Pesaran et al. (2001) emphasized that an F-test would suit to observe whether or not there is co-integration relation between variables. Using the optimal lags, F-test was performed on equation 1 to 3 as reported in Table 3 . The results indicated in Table 3 shows that the F-statistic 9.5676, calculated for equation (1) is higher than the upper bound value. The null hypothesis of no cointegration between the variables is rejected. The conclusion for equation (1) is that there is a long-run relation between the variables. The electricity consumption equation (2), the F-statistic calculated 6.3004 are higher than the upper bound value at $1 \%, 5 \%$ and $10 \%$ level of significance. This indicates that the null hypothesis of no co-integration is rejected. The F-statistic 1.5876 estimated for equation (3), the inflation equation, was lower than the upper bound value even at a $10 \%$ level of significance. Hence, the null hypothesis of no co-integration is inclusive. Results of short-run relationship are shown on the appendix. Where the coefficient of ECM (-1) is statistical significance at $1 \%$ level of significance, which indicates that the speed of adjustment for short run to reach the long-run equilibrium. 
Table 3 ARDL Bound test for Co-integration

\begin{tabular}{lll}
\hline Dependent variables & F-Statistics & Function \\
\hline InY & 9.5676 & InY (InEC, InINF) \\
InEC & 6.3004 & InEC (InY, InINF) \\
InINF & 1.5876 & InINF (InEC, InY) \\
\hline
\end{tabular}

Source: Author used EViews 10

\subsection{Granger causality test}

After establishing the co-integration relation between variables, the next is to test the direction of the causality among the variables. The co-integration suggests the existence of causality at least in one direction. The results for testing of the presence and direction of causality between economic growth, electricity consumption, and inflation are presented in Table 4. The findings indicate a unidirectional between inflation and economic growth with Fstatistic 10.0812 meaning we fail to accept the null hypothesis of LINF does not Granger cause LGDP at 1\% level of significance. These results are constant with Odhiambo (2014); Shahbhaz et al. (2013); Tsani (2010); Ho and Siu (2007) and Wolde-Rufael (2004). There is no causality between electricity consumption and economic growth, these results are in line with as Stern and Enflo (2013); Ozturk and Acaravci (2010); Narayan and Prasad (2008), meaning that both variables are interdependent to each other. But differ from those of Kraft and Kraft (1978); Aslan (2014); Ogundipe and Apata (2013) and Shiu and Lam (2004), who found unidirectional and bidirectional causality.

Table 4 Pairwise Granger Causality Test

\begin{tabular}{lccc}
\hline Null Hypothesis & F-Statistic & Probability & Decision \\
\hline LELE does not Granger Cause LGDP & 2.4453 & 0.1050 & Accept \\
LGDP does not Granger Cause LELE & 0.9675 & 0.3924 & Accept \\
LINF does not Granger Cause LGDP & 10.081 & $0.0005^{* * *}$ & Reject \\
LGDP does not Granger Cause LINF & 0.2617 & 0.7716 & Accept \\
\hline
\end{tabular}

*** denotes the level of significance at $1 \%$.

Source: Author used EViews 10

\section{Conclusion and Recommendations}

This study investigated the causal link between economic growth, electricity consumption, and inflation, using South African annual time series data from 1980-2014, to form a trivariate outline in the analysis. The main findings were as follows: First, the study found that all variables were non-stationary at the level and became stationary at their first difference, meaning the variables were integrated at order one $I(1)$. Using Augmented Dicky-Fuller (ADF) and Phillips-Perron (PP). Second, using the Autoregressive Distributed Lag (ARDL) model, the study found the presence of long-run equilibrium co-integration between the variables. Third, the study found a unidirectional running from inflation to economic growth, which supports the growth hypothesis. Lastly, there was no causality between electricity consumption and economic growth, supporting the neutrality hypothesis, this results are in line Acaravci and Ozturk (2010) and Chen et al. (2007) but differ from previous studies of Kraft and Kraft (1978); Aslan (2014); Ogundipe and Apata (2013) and Shiu and Lam (2004), who found unidirectional and bidirectional causality between these two variables. By employing Pairwise Granger causality test, the direction of causality among the variables was determined.

These results may suffer from omitting other relevant variables; future research should attempt to include more relevant variables in the analysis. This study may contribute to the existing literature especially for South Africa. There were unavoidable limitations, first the study used data from 1980 to 2014, the current was not included due to the unavailability of data and some variables have limited periods. This study can be influential in the formation of policies that can avoid negative effects on economic growth. Any policies concerning energy consumption should be re-evaluated to confirm that it will not disturb economic growth.

\section{Acknowledgments}

We would like to express our sincere gratitude to the editors and two anonymous referees of this Journal, whose constructive comments and suggestions have improved the paper tremendously. We are also grateful to Kabasele Bambe Eddy for his input in this paper. Not forgetting the Department of Higher Education and Training (DHET) and China Scholarship Council (CSC), and the Chinese Academy of Agricultural Sciences (CAAS). The views expressed in this paper are the author's and do not necessarily reflect the views of Institute of Agricultural Economics and Development (IAED). All remaining errors are our own.

\section{References}

Akinlo, A. E. (2008a). Electricity Consumption and Economic Growth in Nigeria: Evidence from Co-Integration 
and Co-Feature Analysis. Journal of Policy Modelling 31 (5): 681-693.

Amusa, K., and Leshoro, T. L. A. (2013). The Relationship between Electricity Consumption and Economic Growth in Botswana. Corporate Ownership \& Control 10 (4): 401-406.

Asafu-Adjaye, J. (2000). The Relationship between Energy Consumption,

Energy Prices and Economic Growth: Time Series Evidence from Asian Developing Countries. Energy Economics 22 (6): 615-625.

Aslan, A., Apergis, N., and Yildri, S. (2014). Causality between Energy Consumption and GDP in the US: Evidence from Wavelet Analysis. Frontiers in Energy 8 (1): 18.

Azlina, A. A. (2012). Energy Consumption and Economic Development in Malaysia: A Multivariate CoIntegration Analysis. Procedia-Social and Behavioral Sciences, 65, 674-681.

Baranzini, A., Weber, S. and Mathys, N.A. (2013). The Causal Relationship between Energy Use and Economic Growth in Switzerland. Energy Economics, 36, 464-470.

Belloumi, M. (2009). Energy Consumption and GDP in Tunisia: Cointegration and Causality Analysis. Energy Policy 37:2745-2753.

Chen, S. T., Kuo H. I. and Chen C. C., (2007). The relationship between GDP and electricity consumption in 10 Asian countries. Energy Policy, 35, 2611-2621.

Glasure, Y.U., and Lee, A. R. (1997). Co-Integration, Error-Correction, and the Relationship between GDP and Energy: The Case of South Korea and Singapore. Resource and Energy Economics 20 (1): 17-25.

Gujarati D. N. and Porter D. C. (2009) Basic Econometrics, McGraw-Hill Irwin.

Ho, C.Y., and. Siu, K. W (2007). A Dynamic Equilibrium of Electricity Consumption and GDP in Hong Kong: An Empirical Investigation. Energy Policy 35:2507-2513.

Kraft, J. and Kraft, A. (1978). On the Relationship between Energy and GNP. Journal of Energy Development, 3 , 401-403.

Jumbe, C.B.L. (2004). Cointegration and causality between electricity consumption and GDP: Empirical evidence from Malawi. Energy Economics, 26, 61-68.

Masih, A. M. M., and Masih, R. (1997). On Temporal Causal Relationship between Energy Consumption, Real Income and Prices: Some New Evidence from Asian Energy Dependent nics Based on a Multivariate Cointegration/Vector Error Correction Approach. Journal of Policy Modelling 19 (4): 417-440.

Narayan, P.K. and Smyth, R. (2005). Electricity consumption, employment and real income in Australia evidence from multivariate Granger causality tests. Energy Policy, 33, 1109-1116.23.

Narayan, P.K. and Prasad, A. (2008). Electricity consumption-real GDP causality nexus: Evidence from a bootstrapped causality test for 30 OECD countries. Energy Policy, 36, 910-918.

Odhiambo, N. M. (2014). Energy Dependence in Developing Countries: Does the Level of Income Matter? Atlantic Economics Journal 42 (1): 65-77.

Ouedraogo, N. S. (2013). Energy Consumption and Economic Growth: Evidence from the Economic Community of West African States (ECOWAS). Energy Economics 36 (c): 637-647.

Ozturk, I., and A. Acaravci. (2010). CO2 Emissions, Energy Consumption and Economic Growth in Turkey. Renewable and Sustainable Energy Reviews 14 (9): 3220-3225.

Ozturk, I. (2010). A literature survey on energy-growth nexus. Energy Policy, 38, 340-349.

Ozturk, I. and Acaravci, A. (2011). Electricity consumption and real GDP causality nexus: Evidence from ARDL bounds testing approach for 11 MENA countries. Applied Energy, 88, 2885-2892

Pesaran, M. H., Shin, Y. C. and Smith, R. (2001). Bound Testing Approaches to the Analysis of Level Relationships. Journal of Applied Econometrics 16 (3): 289-326.

Shui, A. and Lam, P.L. (2004). Electricity Consumption and Economic Growth in China. Energy Policy, 32, $47-$ 54.

Soytas, U. and Sari, R. (2003). Energy Consumption and GDP: Causality Relationship in G7 Countries and Emerging Markets. Energy Economics, 25, 33-37.

Stern, D. I. and Enflo, K. (2013). Causality between Energy and Output in the Long-Run. Energy Economics 39:135-146.

Tsani, S. Z. (2010). Energy Consumption and Economic Growth: A Causality Analysis for Greece. Energy Economics 32 (3): 582-590.

Wolde-Rufael, Y. (2006). Electricity consumption and economic growth: a time series experience for 17 African countries. Energy Policy, 34, 1106-1114.

Yang, H. (2000). A Note on the Causal Relationship between Energy and GDP in Taiwan.' Energy Economics 22 (3): 309-317.

Zhang, Y. J. (2011). Interpreting the Dynamic Nexus between Energy Consumption and Economic Growth: Empirical Evidence from Russia. Energy Policy 39 (5): 2265-2272.

Zhang, X. P. and Cheng X. M. (2009). Energy Consumption, Carbon Emissions, and Economic Growth in China. Ecological Economics 68 (10):2706-2712. 


\section{Appendix A: Data Set}

\begin{tabular}{|c|c|c|c|}
\hline & Economic Growth & Electricity & Inflation \\
\hline YEAR & LGDP & LELE & LINF \\
\hline 1980 & 6447.094 & 3376.929 & 13.66025 \\
\hline 1981 & 6620.851 & 3534.312 & 15.25424 \\
\hline 1982 & 6427.623 & 3609.003 & 14.63904 \\
\hline 1983 & 6150.042 & 3654.42 & 12.30321 \\
\hline 1984 & 6305.916 & 3900.001 & 11.52648 \\
\hline 1985 & 6084.253 & 3989.458 & 16.29423 \\
\hline 1986 & 5951.199 & 4084.439 & 18.65492 \\
\hline 1987 & 5948.618 & 4064.604 & 16.16059 \\
\hline 1988 & 6070.901 & 4152.287 & 12.77955 \\
\hline 1989 & 6085.949 & 4177.063 & 14.73088 \\
\hline 1990 & 5934.224 & 4152.977 & 14.32099 \\
\hline 1991 & 5739.733 & 4051.059 & 15.33477 \\
\hline 1992 & 5485.441 & 3927.213 & 13.8747 \\
\hline 1993 & 5423.588 & 3956.758 & 9.717447 \\
\hline 1994 & 5474.197 & 4003.843 & 8.938547 \\
\hline 1995 & 5528.169 & 4093.122 & 8.680425 \\
\hline 1996 & 5657.328 & 4633.82 & 7.354126 \\
\hline 1997 & 5706.175 & 4744.597 & 8.59777 \\
\hline 1998 & 5643.261 & 4535.281 & 6.880553 \\
\hline 1999 & 5688.309 & 4399.498 & 5.181491 \\
\hline 2000 & 5837.885 & 4503.774 & 5.338953 \\
\hline 2001 & 5912.67 & 4226.646 & 5.701901 \\
\hline 2002 & 6045.963 & 4444.525 & 9.164038 \\
\hline 2003 & 6142.94 & 4470.822 & 5.85898 \\
\hline 2004 & 6343.03 & 4498.979 & 1.385382 \\
\hline 2005 & 6599.357 & 4547.651 & 3.3993 \\
\hline 2006 & 6892.362 & 4638.224 & 4.641625 \\
\hline 2007 & 7185.753 & 4777.059 & 7.09842 \\
\hline 2008 & 7337.84 & 4606.629 & 11.53645 \\
\hline 2009 & 7145.784 & 4385.254 & 7.13 \\
\hline 2010 & 7275.382 & 4510.217 & 4.257416 \\
\hline 2011 & 7416.714 & 4543.628 & 5.000473 \\
\hline 2012 & 7475.781 & 4352.392 & 5.653583 \\
\hline 2013 & 7551.963 & 4279.248 & 5.751534 \\
\hline 2014 & 7582.553 & 4198.401 & 6.067198 \\
\hline
\end{tabular}


Appendix B: Unit Root Test Results

a) Variable InGDP (Economic Growth)

Null Hypothesis: D(LGDP) has a unit root

Exogenous: Constant

Lag Length: 0 (Automatic - based on SIC, maxlag=8)

t-Statistic

Prob.*

Augmented Dickey-Fuller test statistic Test critical values:

$1 \%$ level

$-3.577387$

0.0119

$5 \%$ level

$-3.646342$

$10 \%$ level

$-2.954021$

$-2.615817$

*MacKinnon (1996) one-sided p-values.

Augmented Dickey-Fuller Test Equation

Dependent Variable: D(LGDP,2)

Method: Least Squares

Date: 10/18/18 Time: 04:09

Sample (adjusted): 19822014

Included observations: 33 after adjustments

\begin{tabular}{|c|c|c|c|c|}
\hline Variable & Coefficient & Std. Error & t-Statistic & Prob. \\
\hline $\begin{array}{c}\mathrm{D}(\operatorname{LGDP}(-1)) \\
\mathrm{C}\end{array}$ & $\begin{array}{r}-0.572072 \\
0.002059\end{array}$ & $\begin{array}{l}0.159913 \\
0.004040\end{array}$ & $\begin{array}{r}-3.577387 \\
0.509558\end{array}$ & $\begin{array}{l}0.0012 \\
0.6140\end{array}$ \\
\hline R-squared & 0.292200 & Mean dependent var & & -0.000683 \\
\hline Adjusted R-squared & 0.269368 & S.D. dependent var & & 0.026659 \\
\hline S.E. of regression & 0.022788 & Akaike info criterion & & -4.666516 \\
\hline Sum squared resid & 0.016097 & Schwarz criterion & & -4.575819 \\
\hline Log likelihood & 78.99752 & Hannan-Quinn criter. & & -4.635999 \\
\hline F-statistic & 12.79770 & Durbin-Watson stat & & 1.748961 \\
\hline Prob(F-statistic) & 0.001164 & & & \\
\hline
\end{tabular}


b) Variable InEle (Electricity)

Null Hypothesis: D(LELE) has a unit root

Exogenous: Constant

Lag Length: 0 (Automatic - based on SIC, maxlag=8)

t-Statistic

Prob.*

Augmented Dickey-Fuller test statistic Test critical values:

$1 \%$ level

$-4.923139$

0.0003

*MacKinnon (1996) one-sided p-values.

Augmented Dickey-Fuller Test Equation

Dependent Variable: D(LELE,2)

Method: Least Squares

Date: 10/18/18 Time: 04:13

Sample (adjusted): 19822014

Included observations: 33 after adjustments

\begin{tabular}{|c|c|c|c|c|}
\hline Variable & Coefficient & Std. Error & $\mathrm{t}$-Statistic & Prob. \\
\hline $\begin{array}{c}\mathrm{D}(\operatorname{LELE}(-1)) \\
\mathrm{C}\end{array}$ & $\begin{array}{r}-0.866924 \\
0.004263\end{array}$ & $\begin{array}{l}0.176092 \\
0.006501\end{array}$ & $\begin{array}{r}-4.923139 \\
0.655740\end{array}$ & $\begin{array}{l}0.0000 \\
0.5168\end{array}$ \\
\hline $\begin{array}{l}\text { R-squared } \\
\text { Adjusted R-squared } \\
\text { S.E. of regression } \\
\text { Sum squared resid } \\
\text { Log likelihood } \\
\text { F-statistic } \\
\text { Prob(F-statistic) }\end{array}$ & $\begin{array}{l}0.438785 \\
0.420681 \\
0.036631 \\
0.041597 \\
63.33275 \\
24.23730 \\
0.000027\end{array}$ & $\begin{array}{l}\text { Mean dependent var } \\
\text { S.D. dependent var } \\
\text { Akaike info criterion } \\
\text { Schwarz criterion } \\
\text { Hannan-Quinn criter. } \\
\text { Durbin-Watson stat }\end{array}$ & & $\begin{array}{r}-0.001958 \\
0.048128 \\
-3.717137 \\
-3.626439 \\
-3.686620 \\
1.980511\end{array}$ \\
\hline
\end{tabular}




\section{c) Variable InINF (Inflation)}

Null Hypothesis: D(LINF) has a unit root

Exogenous: Constant

Lag Length: 3 (Automatic - based on SIC, maxlag=8)

\begin{tabular}{llll}
\hline \hline & & t-Statistic & Prob. $^{*}$ \\
\hline \hline Augmented Dickey-Fuller test statistic & & -5.494024 & 0.0001 \\
\hline Test critical values: & $1 \%$ level & -3.670170 & \\
& $5 \%$ level & -2.963972 & \\
& $10 \%$ level & -2.621007 & \\
\hline \hline
\end{tabular}

*MacKinnon (1996) one-sided p-values.

Augmented Dickey-Fuller Test Equation

Dependent Variable: D(LINF,2)

Method: Least Squares

Date: 10/18/18 Time: 04:18

Sample (adjusted): 19852014

Included observations: 30 after adjustments

\begin{tabular}{|c|c|c|c|c|}
\hline Variable & Coefficient & Std. Error & t-Statistic & Prob. \\
\hline D(LINF(-1)) & -2.492338 & 0.453645 & -5.494024 & 0.0000 \\
\hline $\mathrm{D}(\operatorname{LINF}(-1), 2)$ & 1.284478 & 0.363328 & 3.535311 & 0.0016 \\
\hline $\mathrm{D}(\operatorname{LINF}(-2), 2)$ & 0.718468 & 0.265164 & 2.709519 & 0.0120 \\
\hline $\mathrm{D}(\operatorname{LINF}(-3), 2)$ & 0.484863 & 0.177055 & 2.738489 & 0.0112 \\
\hline $\mathrm{C}$ & -0.072137 & 0.066793 & -1.080006 & 0.2904 \\
\hline R-squared & 0.690925 & Mean dependent var & & 0.003955 \\
\hline Adjusted R-squared & 0.641473 & S.D. dependent var & & 0.595026 \\
\hline S.E. of regression & 0.356285 & Akaike info criterion & & 0.924838 \\
\hline Sum squared resid & 3.173467 & Schwarz criterion & & 1.158371 \\
\hline Log likelihood & -8.872566 & Hannan-Quinn criter. & & 0.999547 \\
\hline F-statistic & 13.97164 & Durbin-Watson stat & & 1.924507 \\
\hline Prob(F-statistic) & 0.000004 & & & \\
\hline
\end{tabular}

Dependent Variable: LGDP

Method: ARDL

Date: 01/31/19 Time: 23:00

Sample (adjusted): 19812014

Included observations: 34 after adjustments

Maximum dependent lags: 1 (Automatic selection)

Model selection method: Akaike info criterion (AIC)

Dynamic regressors (2 lags, automatic): LELE LINF

Fixed regressors: $\mathrm{C}$

Number of models evalulated: 9

Selected Model: ARDL $(1,1,1)$

Note: final equation sample is larger than selection sample

\begin{tabular}{|c|c|c|c|c|}
\hline Variable & Coefficient & Std. Error & t-Statistic & Prob.* \\
\hline LGDP(-1) & 1.000057 & 0.031164 & 32.08992 & 0.0000 \\
\hline LELE & 0.315755 & 0.097074 & 3.252712 & 0.0030 \\
\hline $\operatorname{LELE}(-1)$ & -0.261667 & 0.082125 & -3.186207 & 0.0035 \\
\hline LINF & -0.008250 & 0.008217 & -1.004041 & 0.3240 \\
\hline $\operatorname{LINF}(-1)$ & -0.019160 & 0.008878 & -2.158059 & 0.0396 \\
\hline $\mathrm{C}$ & -0.390953 & 0.543757 & -0.718984 & 0.4781 \\
\hline R-squared & 0.979275 & Mean dependent var & & 8.744965 \\
\hline Adjusted R-squared & 0.975574 & S.D. dependent var & & 0.105986 \\
\hline S.E. of regression & 0.016565 & Akaike info criterion & & -5.204321 \\
\hline Sum squared resid & 0.007683 & Schwarz criterion & & -4.934963 \\
\hline Log likelihood & 94.47345 & Hannan-Quinn criter. & & -5.112462 \\
\hline F-statistic & 264.5994 & Durbin-Watson stat & & 1.781875 \\
\hline Prob(F-statistic) & 0.000000 & & & \\
\hline
\end{tabular}

*Note: p-values and any subsequent tests do not account for model selection. 
Appendix D: Long-Run and Short-Run Relationship.

System: UNTITLED

Estimation Method: Least Squares

Date: 01/31/19 Time: 22:53

Sample: 19822014

Included observations: 33

Total system (balanced) observations 99

\begin{tabular}{|c|c|c|c|c|}
\hline & Coefficient & Std. Error & t-Statistic & Prob. \\
\hline $\mathrm{C}(1)$ & -0.004491 & 0.001522 & -2.951265 & 0.0041 \\
\hline $\mathrm{C}(2)$ & 0.073091 & 0.214164 & 0.341286 & 0.7337 \\
\hline $\mathrm{C}(3)$ & -0.022166 & 0.108567 & -0.204169 & 0.8387 \\
\hline C(4) & -0.006562 & 0.009392 & -0.698678 & 0.4867 \\
\hline $\mathrm{C}(5)$ & 0.003747 & 0.003536 & 1.059700 & 0.2923 \\
\hline $\mathrm{C}(6)$ & 0.003567 & 0.002855 & 1.249221 & 0.2151 \\
\hline $\mathrm{C}(7)$ & 0.157838 & 0.401858 & 0.392771 & 0.6955 \\
\hline $\mathrm{C}(8)$ & 0.091698 & 0.203715 & 0.450129 & 0.6538 \\
\hline $\mathrm{C}(9)$ & -0.023374 & 0.017623 & -1.326287 & 0.1883 \\
\hline$C(10)$ & 0.003190 & 0.006634 & 0.480920 & 0.6318 \\
\hline $\mathrm{C}(11)$ & -0.010379 & 0.030681 & -0.338277 & 0.7360 \\
\hline$C(12)$ & 4.038638 & 4.317879 & 0.935329 & 0.3523 \\
\hline$C(13)$ & 1.033204 & 2.188877 & 0.472025 & 0.6381 \\
\hline$C(14)$ & -0.067856 & 0.189359 & -0.358349 & 0.7210 \\
\hline$C(15)$ & -0.056490 & 0.071282 & -0.792484 & 0.4303 \\
\hline
\end{tabular}

Determinant residual covariance

2.60E-08

Equation: D(LGDP) $=\mathrm{C}(1) *($ LGDP(-1) - 22.2158351949*LELE(-1) + $3.59847750601 * \operatorname{LINF}(-1)+169.215092092)+\mathrm{C}(2) * \mathrm{D}(\mathrm{LGDP}(-1))+$ $\mathrm{C}(3) * \mathrm{D}(\operatorname{LELE}(-1))+\mathrm{C}(4) * \mathrm{D}(\operatorname{LINF}(-1))+\mathrm{C}(5)$

Observations: 33

\begin{tabular}{llll}
\hline R-squared & 0.465673 & Mean dependent var & 0.004110 \\
Adjusted R-squared & 0.389340 & S.D. dependent var & 0.024885 \\
S.E. of regression & 0.019446 & Sum squared resid & 0.010588 \\
Durbin-Watson stat & 1.923568 & &
\end{tabular}

Equation: D $($ LELE $)=\mathrm{C}(6) *(\operatorname{LGDP}(-1)-22.2158351949 * \operatorname{LELE}(-1)+$ $3.59847750601 * \operatorname{LINF}(-1)+169.215092092)+\mathrm{C}(7) * \mathrm{D}(\operatorname{LGDP}(-1))+$ $\mathrm{C}(8) * \mathrm{D}(\operatorname{LELE}(-1))+\mathrm{C}(9) * \mathrm{D}(\operatorname{LINF}(-1))+\mathrm{C}(10)$

Observations: 33

\begin{tabular}{|c|c|c|}
\hline R-squared & Mean dependent var & 0.005218 \\
\hline Adjusted R-squared & S.D. dependent var & 0.036385 \\
\hline S.E. of regression & Sum squared resid & 0.037280 \\
\hline Durbin-Watson stat & 2.009981 & \\
\hline \multicolumn{3}{|c|}{$\begin{array}{l}\text { Equation: } \mathrm{D}(\mathrm{LINF})=\mathrm{C}(11) *(\mathrm{LGDP}(-1)-22.2158351949 * \operatorname{LELE}(-1)+ \\
\text { 3.59847750601*LINF(-1) + 169.215092092) + C(12)*D(LGDP(-1)) + } \\
\text { C(13)*D(LELE }(-1))+\mathrm{C}(14) * \mathrm{D}(\operatorname{LINF}(-1))+\mathrm{C}(15) \\
\text { Observations: } 33\end{array}$} \\
\hline R-squared & Mean dependent var & -0.027938 \\
\hline Adjusted R-squared & S.D. dependent var & 0.393182 \\
\hline S.E. of regression & Sum squared resid & 4.303977 \\
\hline Durbin-Watson stat & 1.980865 & \\
\hline
\end{tabular}


Appendix E: Pairwise Granger Causality Test

Pairwise Granger Causality Tests

Date: 01/31/19 Time: 23:02

Sample: 19802014

Lags: 2

\begin{tabular}{lccc}
\hline \hline Null Hypothesis: & Obs & F-Statistic & Prob. \\
\hline \hline LELE does not Granger Cause LGDP & 33 & 2.44530 & 0.1050 \\
LGDP does not Granger Cause LELE & & 0.96757 & 0.3924 \\
\hline \hline LINF does not Granger Cause LGDP & 33 & 10.0812 & 0.0005 \\
LGDP does not Granger Cause LINF & & 0.26175 & 0.7716 \\
\hline \hline LINF does not Granger Cause LELE & 33 & 1.91196 & 0.1666 \\
LELE does not Granger Cause LINF & & 2.00042 & 0.1542 \\
\hline
\end{tabular}

\section{Appendix E: Diagnostics Tests}

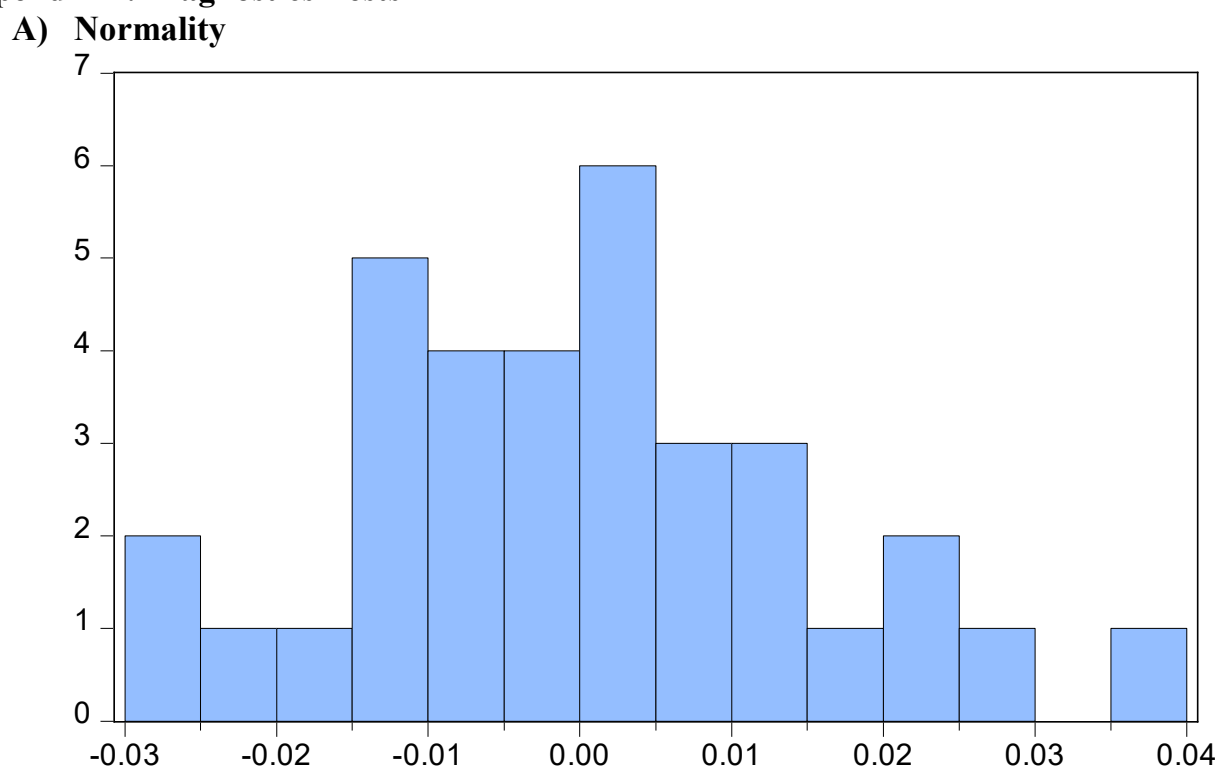

$\begin{array}{ll}\text { Series: Residuals } \\ \text { Sample 1981 } 2014 \\ \text { Observations } 34 \\ \text { Mean } & -1.99 \mathrm{e}-16 \\ \text { Median } & -0.000655 \\ \text { Maximum } & 0.035795 \\ \text { Minimum } & -0.029860 \\ \text { Std. Dev. } & 0.015258 \\ \text { Skewness } & 0.261488 \\ \text { Kurtosis } & 2.819448 \\ & \\ \text { Jarque-Bera } & 0.433646 \\ \text { Probability } & 0.805073\end{array}$

B) Autocorrelation

VEC Residual Serial Correlation LM Tests

Date: 01/31/19 Time: 02:07

Sample: 19802014

Included observations: 33

Null

hypothesis

\begin{tabular}{ccccccc}
\hline \hline Lag & LRE* stat & df & Prob. & Rao F-stat & df & Prob. \\
\hline \hline 1 & 5.313100 & 9 & 0.8062 & 0.581202 & $(9,56.1)$ & 0.8069 \\
\hline \hline
\end{tabular}


C) Hetoskedasticity

Heteroskedasticity Test: Breusch-Pagan-Godfrey

\begin{tabular}{llll}
\hline \hline F-statistic & 3.752521 & Prob. F(5,28) & 0.0100 \\
Obs*R-squared & 13.64185 & Prob. Chi-Square(5) & 0.0181 \\
Scaled explained SS & 8.416686 & Prob. Chi-Square(5) & 0.1347
\end{tabular}

Test Equation:

Dependent Variable: RESID ${ }^{\wedge} 2$

Method: Least Squares

Date: 01/31/19 Time: 23:09

Sample: 19812014

Included observations: 34

\begin{tabular}{|c|c|c|c|c|}
\hline Variable & Coefficient & Std. Error & t-Statistic & Prob. \\
\hline $\mathrm{C}$ & 0.009093 & 0.008531 & 1.065787 & 0.2956 \\
\hline $\operatorname{LGDP}(-1)$ & 0.000481 & 0.000489 & 0.984607 & 0.3332 \\
\hline LELE & $9.45 \mathrm{E}-05$ & 0.001523 & 0.062050 & 0.9510 \\
\hline $\operatorname{LELE}(-1)$ & -0.001698 & 0.001289 & -1.317894 & 0.1982 \\
\hline LINF & 0.000168 & 0.000129 & 1.300473 & 0.2040 \\
\hline $\operatorname{LINF}(-1)$ & $-2.06 \mathrm{E}-05$ & 0.000139 & -0.147937 & 0.8835 \\
\hline R-squared & 0.401231 & Mean dependent var & & 0.000226 \\
\hline Adjusted R-squared & 0.294308 & S.D. dependent var & & 0.000309 \\
\hline S.E. of regression & 0.000260 & Akaike info criterion & & -13.51381 \\
\hline Sum squared resid & $1.89 \mathrm{E}-06$ & Schwarz criterion & & -13.24445 \\
\hline Log likelihood & 235.7347 & Hannan-Quinn criter. & & -13.42195 \\
\hline F-statistic & 3.752521 & Durbin-Watson stat & & 2.304036 \\
\hline Prob(F-statistic) & 0.010018 & & & \\
\hline
\end{tabular}

D) Stability

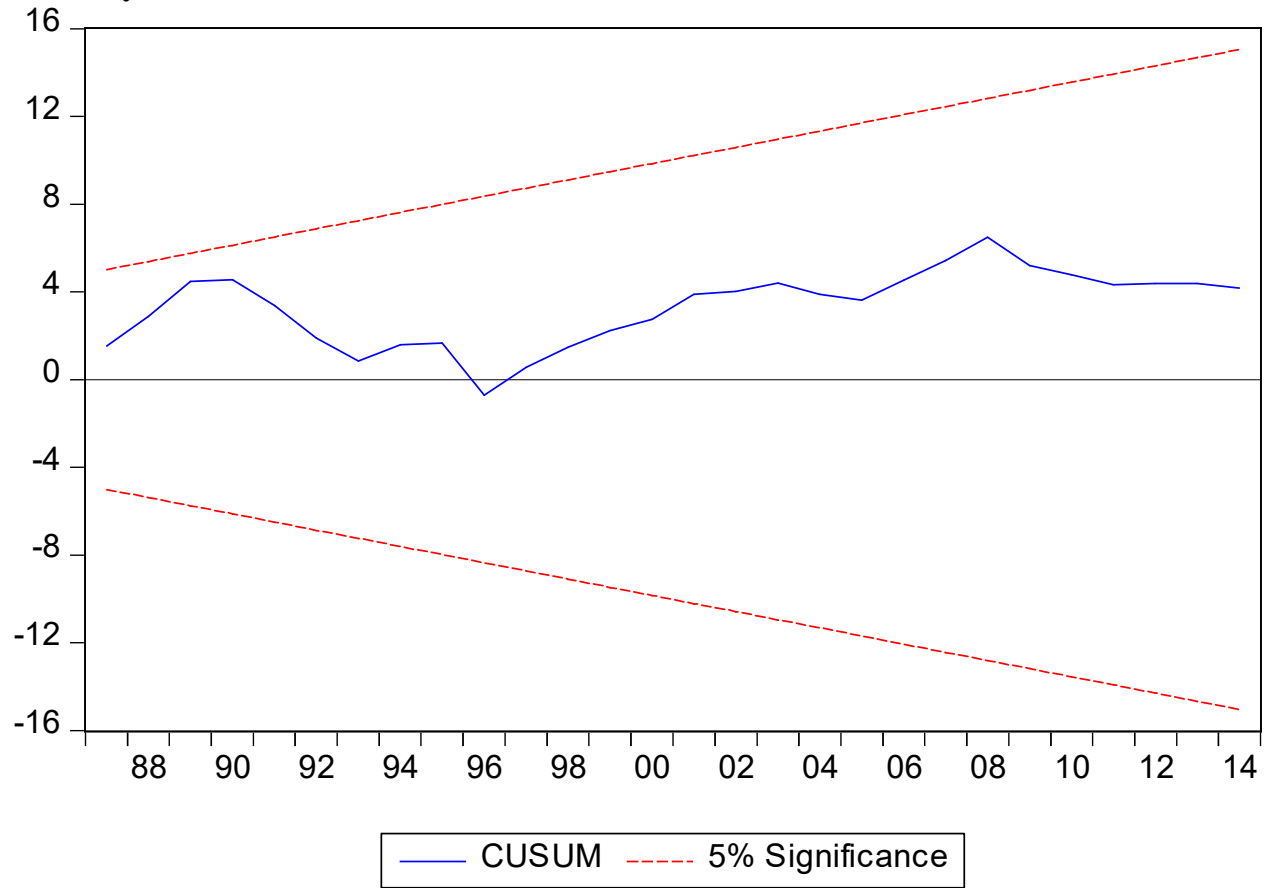

